\title{
Improving, Restoring, and Managing Wildlife Habitat in Florida: Sources of Technical Assistance for Rural Landowners 1
}

Martin Main, Chris Demers, and Mark Hostetler²

\section{Introduction}

In Florida, roughly $50 \%$ of the rural land area is held in private ownership and engaged in some form of agriculture or forestry (Florida Statistical Abstract, 1992). Privately owned lands in Florida provide critically important wildlife habitat for many species. Effective management of wildlife habitat on private lands in Florida is essential for maintaining healthy wildlife populations into the future.

Managing for wildlife essentially includes maintaining the natural processes on the land. For example, fire in pine flatwoods and seasonal flooding of wetlands are essential for maintaining plant and wildlife communities that are adapted to these natural processes. However, multiple land uses, invasive non-native species, and other factors may interfere with natural environmental processes. In these cases, active management is needed to maintain or restore healthy and productive wildlife habitat.
Expert advice can be helpful when deciding on specific management actions needed to maintain or restore wildlife habitat. This is especially useful when attempting to benefit wildlife species of special management interest or concern. Landowners are advised to consider the types of habitats that exist on their property and that they are interested in managing, such as wetlands, pine forests, hardwoods, abandoned pasture, and so forth, to assist them when they begin searching for information.

This document summarizes sources of information from federal, state, and non-governmental organizations that provide technical assistance to rural landowners interested in managing or restoring habitat for wildlife (Table 1). Additional information regarding conservation and management of wildlife habitat in Florida is available on the University of Florida/IFAS Cooperative Extension Electronic Data Information Source (EDIS). Related documents present information on programs that provide:

1. This document is Circular 1472, one of a series of the Wildlife Ecology and Conservation Department, Florida Cooperative Extension Service, Institute of Food and Agricultural Sciences, University of Florida. First published: May 2005. Please visit the EDIS Web site at http://edis.ifas.ufl.edu.

2. Martin B. Main, Associate Professor, Department of Wildlife Ecology \& Conservation, Southwest Florida Research and Education Center, Institute of Food and Agricultural Sciences, University of Florida, Immokalee, FL 34142; Mark E. Hostetler, Assistant Professor, Department of Wildlife Ecology \& Conservation, Institute of Food and Agricultural Sciences, University of Florida, Gainesville, FL 32611; and Chris Demers, Forest Stewardship Coordinator, School of Forest Resources and Conservation, Cooperative Extension Service, Institute of Food and Agricultural Sciences, University of Florida, Gainesville, FL 32611.

The Institute of Food and Agricultural Sciences (IFAS) is an Equal Opportunity Institution authorized to provide research, educational information and other services only to individuals and institutions that function with non-discrimination with respect to race, creed, color, religion, age, disability, sex, sexual orientation, marital status, national origin, political opinions or affiliations. U.S. Department of Agriculture, Cooperative Extension Service, University of Florida, IFAS, Florida A. \& M. University Cooperative Extension Program, and Boards of County Commissioners Cooperating. Larry Arrington, Dean 
1. Financial assistance to private landowners

- Improving, Restoring, and Managing Natural Resources on Rural Properties in Florida: Sources of Financial Assistance (http://edis.ifas.ufl.edu/FR156)

- Paying Private Landowners to Conserve Wildlife Habitat: A Unique Approach to Conservation (http://edis.ifas.ufl.edu/UW138)

2. Technical assistance for homeowners:

- Improving, Restoring, and Managing Natural Resources in Florida: Sources of Technical Assistance for Urban Homeowners (http://edis.ifas.ufl.edu/UW212)

3. Conservation options (easements, etc.) for private landowners

- Conservation Options for Private Landowners in Florida (http://edis.ifas.ufl.edu/UW194)

- Conservation Easements: Options for Preserving Current Land Uses (http://edis.ifas.ufl.edu/FR149)

4. Evaluating private lands for conservation

- Evaluating Private Lands for Conservation of Wildlife (http://edis.ifas.ufl.edu/UW195)

- What is in a Natural Resource Management Plan?(http://edis.ifas.ufl.edu/FR126) .

\section{Additional information}

Demers, C., Long, A., and C. Latt. 1999. Establishing and maintaining wildlife food sources. University of Florida/IFAS, Extension Digital Information Source (EDIS) Database. http://edis.ifas.ufl.edu/FR062.

Demers, C., Hawkins, L., Long, A., and C. McKelvy. 2001. Providing wildlife cover. University of Florida/IFAS, Extension Digital Information Source (EDIS) Database. http://edis.ifas.ufl.edu/FR124.

Hostetler, M.E., Klowden, G., Miller, S.W., and K. N. Youngentob. 2003. Landscaping backyards for wildlife: top ten tips for success. University of Florida Cooperative Extension Service Fact Sheet Circ 1429.
University of Florida, UF/IFAS EDIS Database, http://edis.ifas.ufl.edu/UW175.

Jacobson, M., and A. Long. 2003. Ecosystem Management (EM) as a basis for forest stewardship on private lands. University of Florida/IFAS, Extension Digital Information Source (EDIS) Database. http://edis.ifas.ufl.edu/FR046.

Long, A. 2002. Benefits of prescribed burning. University of Florida/IFAS, Extension Digital Information Source (EDIS) Database. http://edis.ifas.ufl.edu/FR061.

Main, M. B., Karim, A.K., and M. E. Hostetler. 2003. Conservation options for private landowners in Florida. University of Florida/IFAS, Extension Digital Information Source (EDIS) Database. http://edis.ifas.ufl.edu/UW194.

Main, M. B., Karim, A. K., and M. E. Hostetler. 2003. Evaluating private lands for conservation of wildlife. University of Florida/IFAS, Extension Digital Information Source (EDIS) Database. http://edis.ifas.ufl.edu/UW195.

Main, M. B., Roka, F. M., and M. E. Hostetler. 2000. Paying private landowners to conserve wildlife habitat: a unique approach to conservation. University of Florida/IFAS, Extension Digital Information Source (EDIS) Database. http://edis.ifas.ufl.edu/UW138.

Main, M. B. 2000. Management of white-tailed deer in Florida - Part I: collecting information on herd health. University of Florida/IFAS, Extension Digital Information Source (EDIS) Database. http://edis.ifas.ufl.edu/UW136.

Main, M.B., and G.W. Tanner. 1999. Effects of fire on Florida's wildlife and wildlife habitat. University of Florida/IFAS, Extension Digital Information Source (EDIS) Database. http://edis.ifas.ufl.edu/UW132.

Marion, W. R., Werner, M., and G. W. Tanner. 2002. Management of pine forests for selected wildlife in Florida. University of Florida/IFAS, Extension Digital Information Source (EDIS) Database. http://edis.ifas.ufl.edu/UW098. 
Moore, S. 1999. Forests, hydrology, and water quality: impacts of silvicultural practices. University of Florida/IFAS, Extension Digital Information Source (EDIS) Database.

http://edis.ifas.ufl.edu/FR009.

University of Florida/IFAS Center for Natural Resources. 2000. Florida's invaders: exotic pests. University of Florida/IFAS, Extension Digital Information Source (EDIS) Database. http://edis.ifas.ufl.edu/CR008. 
Table 1. Organizations and programs that operate throughout Florida (statewide) to provide technical assistance for management of wildlife habitat and natural resources.

\begin{tabular}{|c|c|c|}
\hline Organization & Contact Information & Comments \\
\hline \multicolumn{3}{|l|}{ Federal } \\
\hline \multirow[t]{2}{*}{$\begin{array}{l}\text { Department of the } \\
\text { Interior }\end{array}$} & $\begin{array}{l}\text { U.S. Fish and Wildlife Service, } \\
\text { Partners for Fish \& Wildlife: } \\
\text { http://partners.fws.gov }\end{array}$ & $\begin{array}{l}\text { Assistance to private landowners to restore } \\
\text { wetlands and other wildlife habitat. }\end{array}$ \\
\hline & $\begin{array}{l}\text { Bureau of Reclamation: } \\
\text { http://www.usbr.gov/waterconservation/planning.html }\end{array}$ & $\begin{array}{l}\text { Financing, in-kind services, and educational } \\
\text { programs for on-farm water management. }\end{array}$ \\
\hline \multirow[t]{2}{*}{$\begin{array}{l}\text { U.S. Department } \\
\text { of Agriculture }\end{array}$} & $\begin{array}{l}\text { Natural Resources Conservation Service (NRCS): } \\
\text { http://www.nrcs.usda.gov/programs }\end{array}$ & $\begin{array}{l}\text { Multiple programs that provide technical and } \\
\text { financial support to assist with managing and } \\
\text { restoring wetlands and other wildlife habitat. }\end{array}$ \\
\hline & $\begin{array}{l}\text { Farm Service Agency: } \\
\text { http://www.fsa.usda.gov/pas/ }\end{array}$ & $\begin{array}{l}\text { Technical and financial assistance to address } \\
\text { soil, water, and related natural resource } \\
\text { concerns on farms and ranches. }\end{array}$ \\
\hline \multicolumn{3}{|l|}{ State } \\
\hline $\begin{array}{l}\text { University of } \\
\text { Florida/IFAS }\end{array}$ & $\begin{array}{l}\text { Cooperative Extension Electronic Data Information } \\
\text { Source: } \\
\text { http://edis.ifas.ufl.edu/ }\end{array}$ & $\begin{array}{l}\text { Searchable database for technical information on } \\
\text { many topics related to management of natural } \\
\text { resources. }\end{array}$ \\
\hline $\begin{array}{l}\text { Florida } \\
\text { Cooperative } \\
\text { Extension Service }\end{array}$ & $\begin{array}{l}\text { Cooperative Extension Service County Offices: } \\
\text { http://extension.ifas.ufl.edu }\end{array}$ & $\begin{array}{l}\text { Provide technical assistance and conduct public } \\
\text { workshops. Services vary by county. }\end{array}$ \\
\hline $\begin{array}{l}\text { Florida Fish and } \\
\text { Wildlife } \\
\text { Conservation } \\
\text { Commission }\end{array}$ & $\begin{array}{l}\text { Landowner Incentive Program: } \\
\text { http://www.myfwc.com/lip/ }\end{array}$ & $\begin{array}{l}\text { Financial and technical assistance for } \\
\text { landowners to manage, enhance, or restore } \\
\text { habitats to benefit species at risk. }\end{array}$ \\
\hline $\begin{array}{l}\text { Florida Division of } \\
\text { Forestry }\end{array}$ & $\begin{array}{l}\text { Forest Stewardship Program (FSP): } \\
\text { http://www.fl-dof.com/forest_management/ } \\
\text { cfa_steward_index.html } \\
\text { UF/IFAS FSP web site: } \\
\text { http://www.sfrc.ufl.edu/Extension/ffws/fsp.htm }\end{array}$ & $\begin{array}{l}\text { Technical assistance and educational programs } \\
\text { through cooperation with UF/IFAS, Florida Fish } \\
\text { and Wildlife Conservation Commission, and } \\
\text { other organizations. }\end{array}$ \\
\hline
\end{tabular}


Table 1. Organizations and programs that operate throughout Florida (statewide) to provide technical assistance for management of wildlife habitat and natural resources.

\begin{tabular}{|c|c|c|}
\hline \multirow[t]{3}{*}{$\begin{array}{l}\text { Water } \\
\text { Management } \\
\text { Districts }\end{array}$} & $\begin{array}{l}\text { South Florida Water Management District, Water } \\
\text { Savings Initiative Program: } \\
\text { http://www.sfwmd.gov/org/wsd/wsconservation/ } \\
\text { waterconsfungingprogram.html }\end{array}$ & $\begin{array}{l}\text { Technical assistance to implement } \\
\text { water-efficiency measures that reduce water use } \\
\text { demands and promote water conservation. }\end{array}$ \\
\hline & $\begin{array}{l}\text { Southwest Florida Water Management District, } \\
\text { Facilitating Agricultural Resource Management } \\
\text { Systems (FARMS): } \\
\text { http://www.swfwmd.state.fl.us/business/farms/ }\end{array}$ & $\begin{array}{l}\text { Incentives to farmers to install and maintain } \\
\text { irrigation best management practices (BMPs) to } \\
\text { the agricultural community within "water use } \\
\text { caution areas" (WUCA). }\end{array}$ \\
\hline & $\begin{array}{l}\text { Suwannee River Water Management District, Private } \\
\text { Landowner Initiative Program: } \\
\text { http://www.srwmd.state.fl.us/features/news/ } \\
\text { private+landowner+initiative.htm }\end{array}$ & $\begin{array}{l}\text { Assistance to private landowners to develop and } \\
\text { implement land management plans that } \\
\text { enhance, improve, or restore fish and wildlife } \\
\text { habitat. }\end{array}$ \\
\hline \multicolumn{3}{|c|}{ Non-governmental. } \\
\hline $\begin{array}{l}\text { National Wildlife } \\
\text { Federation }\end{array}$ & $\begin{array}{l}\text { NWF Species Recovery Fund: } \\
\text { http://www.nwf.org/wildlife/grants/index.cfm }\end{array}$ & $\begin{array}{l}\text { Funding and technical assistance for habitat } \\
\text { restoration, species reintroduction, and other } \\
\text { efforts that benefit species listed under the U.S. } \\
\text { Endangered Species Act. }\end{array}$ \\
\hline $\begin{array}{l}\text { American Forest } \\
\text { Foundation }\end{array}$ & $\begin{array}{l}\text { Forests for Watersheds and Wildlife }\left(\mathrm{F}_{2} \mathrm{~W}_{2}\right) \text { : } \\
\text { http://64.177.25.182/cms/pages/51_5.html }\end{array}$ & $\begin{array}{l}\text { Directs forestland owners to AFF volunteer } \\
\text { foresters, conservation groups, land trusts, and } \\
\text { natural resource professionals who can provide } \\
\text { assistance in developing forest conservation and } \\
\text { wildlife management plans to promote wildlife } \\
\text { habitat improvement, watershed protection, and } \\
\text { forest health. }\end{array}$ \\
\hline $\begin{array}{l}\text { Stewardship } \\
\text { America, Inc. }\end{array}$ & $\begin{array}{l}\text { Farmland Stewardship Program: } \\
\text { http://privatelands.org/contents_FSP.htm } \\
\text { (scroll down to program information) }\end{array}$ & $\begin{array}{l}\text { Provides agricultural producers access to } \\
\text { conservation and profit improvement } \\
\text { information. }\end{array}$ \\
\hline
\end{tabular}

